\title{
In the aftermath of the German labor market reforms, is there a qualitative/quantitative trade-off?
}

\author{
Joachim Möller* \\ IAB, Nuremberg and Department of Economics, University of Regensburg, Germany
}

\begin{abstract}
This paper argues that the German labor market reforms implemented in 2003-2005 were successful, according to the main quantitative indicator of labor market conditions. Long-term unemployment decreased substantially in the years after the reform, and the trend of continuously increasing systemic unemployment was reversed. At the same time, the extreme shock to the GDP incurred by the world recession in 2008/2009 left only minor traces in the German labor market. Employment climbed to an all-time high, and several regions, especially Southern Germany, are close to full employment. One should also stress that youth unemployment in the country is among the lowest in Europe.

The evidence from several qualitative indicators of labor market conditions, however, is less clear. Since 2005, these different indicators tell both negative and positive stories. On the positive side, the German 'job miracle' could have played a role in this context. Even during the sharpest recession in the post-war period, employment was stable. My interpretation is that this ameliorated the perceived job stability for many workers. On the negative side, the wage growth for many groups of workers is unsatisfactory. Wage inequality has risen substantially. Today, the size of the low-pay sector in Germany is higher than that in almost all other European countries. I argue that the increase in wage dispersion has gone too far. It was not a necessary condition for the improvement of the employment rate but was instead an unintended by-product of the reforms. Therefore, this side effect can be corrected without jeopardizing the indisputable employment rate successes.
\end{abstract}

Keywords: labor market reforms, unemployment, inequality, quality of jobs

JEL codes: $J 10, J 28, J 31$

\section{INTRODUCTION}

From an international perspective, the German labor market reforms under the socialdemocratic Chancellor Gerhard Schröder in 2003 to 2005 are mostly considered a success story and the key explanation for Germany's strong economy in the aftermath of the reforms. Indeed, the available quantitative labor market indicators show a substantial improvement of the labor market after 2005. These indicators include short- and longterm unemployment, matching efficiency and the employment rates of female workers, the young, and the elderly. Other developments are also favorable. The German youth unemployment rate is among the lowest in Europe. The enormous structural labor market problems in East Germany after reunification seem to be improving because the regional

* I I am grateful to a referee of the paper for valuable suggestions and comments. Thanks also to all discussants at the 17th Conference on 'The Jobs Crisis: Causes, Cures, Constraints,' Berlin, 24-26 October 2013. 
unemployment rates between East and West are converging. Moreover, the contribution to unemployment insurance came down from a maximum of 6.5 percent of the wage bill in 2005 to 3 percent in 2012. A recent study on the fiscal costs of unemployment shows that these costs in nominal terms were reduced by almost 40 percent, from $€ 87.7$ billion in 2005 to $€ 53.8$ billion in 2012 (Hausner et al. 2014). Contributing to this bright picture, the indicators of international competitiveness are also rather strong. In 2013, Germany considerably surpassed the current account surplus of China ( $\$ 260$ billion vs $\$ 195$ billion). As a percentage of GDP, the current account surplus climbed to values hardly ever seen before (7.3 percent in 2013). This imbalance can be criticized from an international macro perspective. The large export volumes, however, indicate that Germany has clearly left its position as the sick man of the euro that the country had in the late 1990s. Last but not least, the German labor market proved to be extremely robust during the Great Recession. Although gross domestic product dropped by almost 6.5 percent relative to trend, unemployment barely responded to this extreme macroeconomic shock. Paul Krugman has termed this astonishing phenomenon as 'Germany's job miracle' (see, for example, Möller 2010; Burda/Hunt 2011; or Boeri/van Ours 2013 for an explanation).

Overall, it is not surprising that over the last few years, Germany has been considered a bastion of stability and even Europe's engine of growth. Therefore, outside observers seem to consider Germany to be a blueprint for successful economic reforms. ${ }^{1}$

However, looking more closely at the situation reveals some less desirable outcomes. First, the low-pay sector in Germany has increased enormously. In 2010, more than 25 percent of German workers fit the definition of a low-paid worker - that is, they were receiving less than two-thirds of the median hourly wage, according to the study by Rhein (2013). The author concludes that in European comparison, this share is rather high, which means that wage inequality in the lower half of the wage distribution is now more pronounced than in most other EU countries' (ibid.: 1). This result is remarkable because Germany was traditionally a relatively egalitarian country, closer to the Scandinavian countries than to the Anglo-Saxon countries. 'Prosperity for everyone' was the consensus vision in German society from the 1950s to the 1970s. It was stated by Ludwig Erhard, minister of the economy and later chancellor of Germany, the father of the German Wirtschaftswunder. During recent years, the principle of letting all groups of workers participate in the growth of income appears to be weakening. In terms of real wages, some groups of workers are worse off compared to 25 years ago. Moreover, there are indications that, for larger groups of workers, job quality has deteriorated. This is more likely to be the case for several, but not all, forms of non-standard employment. Non-standard contracts - comprising marginal employment, voluntary and involuntary part-time and temporary work, and fixed-term contracts - have grown markedly, especially among youths, females, and lowskilled persons. At the same time, union coverage has declined considerably. In large sectors of the economy, workers have low bargaining power and are poorly paid due to the lack of a statutory minimum wage. ${ }^{2}$

The quality of work concerns not only the level of earnings but also job security and job stability, chances of participation, adequate individual careers, and working conditions. These aspects become an even more important issue in the discussion about German labor market policy. The crucial question is whether there is an inner link between the perceived deterioration in the various aspects of job quality and the labor market reforms or

1. Recently, this view has been shared also by François Hollande, the President of France.

2. According to the plans of the grand coalition, a country-wide wage floor will be introduced in 2015 . 
whether this was unintended 'collateral damage.' Under the first alternative, there is a quantitative/qualitative trade-off, implying that the favorable quantitative effects of the labor market reform inevitably come at the cost of lower average job quality. Under the second alternative, the decline in work satisfaction could have been avoided through sensible regulation without jeopardizing the undisputed successes observed in the quantitative labor market indicators.

The remainder of the paper is structured as follows. Section 2 describes the reform process, outlines the basic elements and describes the outcomes, concentrating on the quantitative indicators. Section 3 addresses the qualitative side, with the various aspects of job quality being discussed first, followed by the presentation of some empirical evidence for the development of indicators of job quality, and a discussion about whether a quantitative/ qualitative trade-off exists. Section 4 concludes.

\section{A SKETCH OF THE REFORMS}

\subsection{Why was there a need for reforms?}

As I have argued elsewhere in more detail (Möller 2014), the German economy ran into more and more trouble after the mid 1970s. In particular, the step-wise increase in systemic unemployment became a menacing problem. A detrimental path dependency led to a growing number of outsiders, whose chances of reintegration into the labor market became smaller as the length of their unemployment spells grew. This and other hysteresis mechanisms were described by several authors (for example, Blanchard/Summers 1987; Möller 1990).

German reunification added an additional burden to the situation. The East German economy had to undergo deep structural reforms and its run-down public infrastructure had to be financed with huge investments. Moreover, social security systems - especially the unemployment insurance and the pension system - came under financial distress because of the need to support the high number of unemployed and retired workers in the East. After the bursting of the New Economy bubble, the situation became more drastic. During the first years of the new century, the need for radical measures became obvious. The result was the 'Agenda 2010,' initiated by the government led by the social-democratic Chancellor Gerhard Schröder. The core sentence of Chancellor Schröder's famous speech in March 2003 describes the views of political leaders at that time: 'If Germany refrains from modernizing its labor market institutions then it would be modernized through the brute forces of the global markets leaving barely room for a social protection net.'

Basic elements of the labor market reforms were the main healing force for the German economy. Despite reform skepticism from all sides of the political spectrum, the medication did work. According to reform proponents, the drastic cure has kept the German model alive. If one takes this view as granted, the question remains whether the 'collateral damage' of some parts of the reform were necessary.

\subsection{Basic elements of the reform}

As described by Möller (2014) in more detail, the 'Agenda 2010' aimed to reform central labor market institutions. The Agenda was implemented in steps between 2003 and 2005. It came under the motto 'supporting and demanding.' On the one hand, several instruments for easing the integration of unemployed workers, such as training measures, wage subsidies, and better services for the placement of workers into new jobs, 
were introduced. On the other hand, the reform lowered job protection standards and reduced the maximum length of unemployment insurance benefits. This placed strong pressure on the unemployed. An important change was that the entitlement for unemployment insurance (unemployment benefit I) ends after 12 months with exceptions only for older workers. The so-called unemployment II now replaces benefits from the unemployment insurance system. Unemployment benefits II are being financed by the taxpayer. They are lump sum and means-tested. In contrast, unemployment benefits I are status-oriented - that is, their amount depends on previous earnings (60 or 66 percent of the previous net wage, depending on the existence of dependent children). Hence, losing the entitlement for unemployment insurance means a substantial threat to the social status of the worker. At the same time, job-acceptance rules for the unemployed, together with the possibility of sanctions, were aggravated, whereas regulations for temporary-work agencies were lightened.

The changes created considerable pressure on workers to accept even bad jobs in order not to experience a substantial loss in social status. Furthermore, changes in the behavior of the incumbent workforce are as least as strong as the effects on job seekers. Survey data reveal that employers perceive remarkable higher effort, more flexibility - for example, in the willingness to accept varying working hours - and, albeit to a much lesser extent, even the acceptance of lower wages. Overall, the reforms weakened the bargaining position of workers to push through higher earnings or better working conditions.

\subsection{Quantitative effects of the reform}

Immediately after the reforms, the world economy was in a marked upswing. Hence the overall conditions were favorable for a labor market improvement. The boom in the German economy was especially strong in manufacturing, driven by exporters of machinery, chemical products, and the automotive industry. Unemployment came down from its peak level of approximately 5 million in 2005 to less than 3 million in 2012 (see Figure 1). In 2007, almost

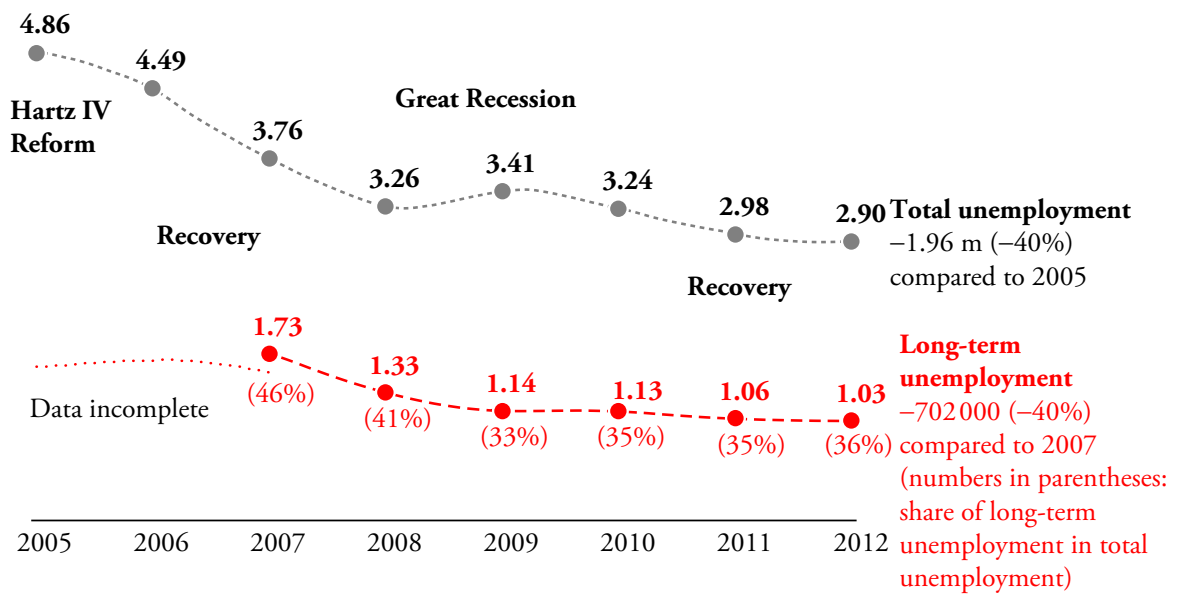

Source: German Federal Employment Agency; Arbeitsmarktberichterstattung.

Figure 1 Total number of unemployed and long-term unemployed (average in millions, Germany 2005 to 2012) 
half of unemployment was long-term unemployment. By 2012, long-term unemployment fell to slightly above 1 million. This meant a reduction of more than 700000 persons since 2007 and of 10 percentage points in the share of long-term unemployment in total unemployment. Given the special problems related to long-term unemployment, the decrease by two-fifths is obviously a success.

Figure 2 shows the unemployment rate in Germany in a long-run perspective. In the immediate post-war period, unemployment was at double-digit levels. The subsequent period of the Wirtschaftswunder in the 1950s and 1960s saw a reduction of the unemployment rate to extremely low levels, only interrupted by a short-lived recession in 1966/1967. Then unemployment grew in steps, following the two oil-price crises and the severe recession after the Bundesbank introduced a contractive monetary policy in the aftermath of German reunification. As observed from Figure 2, the unemployment rates in boom periods increased from one business cycle to the next in a step-wise fashion, thus indicating hysteresis effects, as mentioned above. Through the labor market reforms, a reversal of this unfortunate trend could be achieved. For the first time since the 1960s, systemic unemployment fell, and this favorable development was not stopped by the Great Recession.

Additionally, other indicators of the labor market indicate that the reforms and the following boom period have improved the labor market situation. The reduction in the official unemployment measure cannot be explained by statistical 'tricks.' A wider measure calculated by the Institute for Employment Research (IAB) that includes all persons available to the labor market but not counted as unemployed moves in parallel to the time series shown in Figure 2 (cf. Brücker et al. 2012). Looking at employment instead of unemployment gives a very similar picture. Employment in 2013 has reached an all-time high and total hours worked climbed to levels last seen in the reunification boom 20 years ago. Additionally the shares of the working population relative to the potential workforce are at high levels. Further, youth unemployment is low relative to other countries.

Figure 3 shows the youth unemployment rates for EU 27 and selected European countries in 2005 and 2012. In almost all countries, youth unemployment has increased during recent years. This is especially the case for Greece and Spain, but also for the UK.

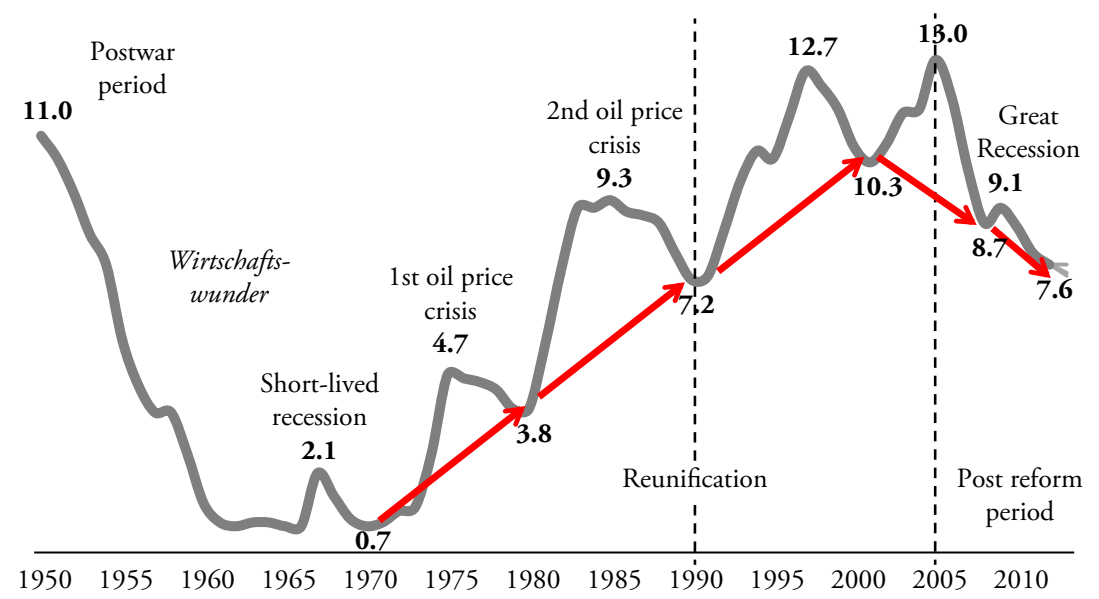

Source: German Federal Employment Agency; Arbeitsmarktberichterstattung.

Figure 2 Unemployment rate (in percent of civil labor force; Germany 1950 to 2012, forecast for 2013) 


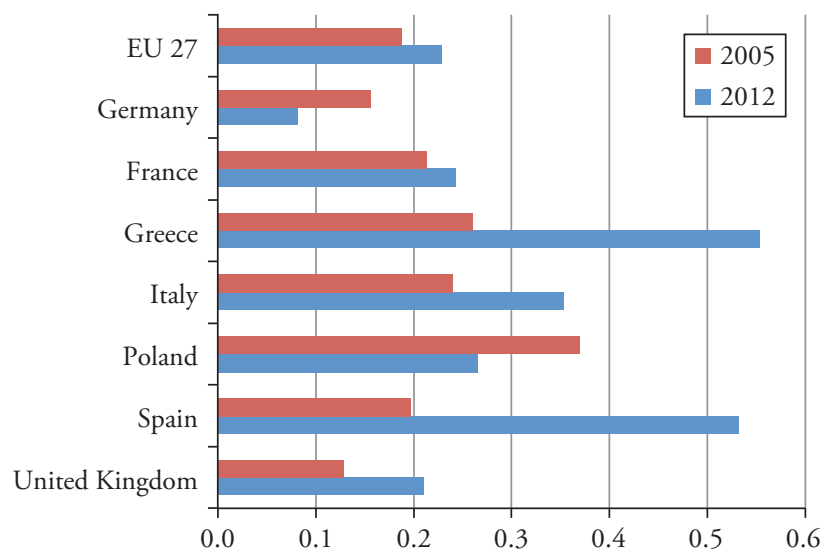

Source: Eurostat Labor Force Survey.

Figure 3 Youth unemployment rates in selected European countries in 2005 and 2012

Only Germany and Poland show decreasing unemployment rates for young workers. With a youth unemployment rate well below 10 percent, youth unemployment is much lower than the European average. In this context, the favorable influence of the German apprenticeship system is an important candidate for explaining the evidence.

\section{QUALITATIVE INDICATORS}

\subsection{What is good work?}

The quality of work life has become an increasingly important topic to personnel economics as an instrument for sustainably ensuring the productivity of a qualified workforce. Numerous studies have focused on the quality of working life and its importance for the performance of private firms or public organizations. Although the concept of the quality of working life is somewhat fuzzy, there is consensus that it should at least encompass the following dimensions: ${ }^{3}$

(i) Adequate rewards and recognition: Do employers pay fair wages? Do earnings ensure the means of subsistence, and do they increase with overall productivity?

(ii) Stability of employment and job protection: Do the employees typically have longterm labor contracts? How long is the average duration of an employment spell?

(iii) Social insurance: Are there adequate provisions for cushioning the risk of unemployment and avoiding the risk of poverty?

(iv) Working conditions: Does the job guarantee safety at the workplace and provide the prerequisites for conserving a good mental and physical health status for the worker over the long run?

3. The European Foundation for the Improvement of Living and Working Conditions (2013) considers five areas: employment conditions, wages, health and safety, skills and competencies, and working time. 
(v) Sustainable employability: Does the job offer training measures for keeping the workers' competences up to date? Are there adequate possibilities for a professional career?

(vi) Co-determination and communication: Does the job offer a right to participate in shaping working conditions - for example, working time flexibility, design of the workplace?

Institutional changes at the macro level are able to influence these various dimensions of job quality. The effect of the German labor market reforms primarily concerns the first three factors. The deregulation of job protection rules or temporary work agencies, for instance, can be expected to affect the average duration of employment spells - that is, the stability of the job. In general, the reforms are likely to have disturbed the 'balance of bargaining power' between workers and firms. This has led to lower wage growth, at least for those who are in a weak market position, such as, for instance, the low-skilled. Therefore, one would expect higher wage dispersion, especially in the lower tail of the wage distribution. An influence on the growth of the low-pay sector could also stem from the sharpening of job-acceptance rules for the unemployed. In contrast, wage-boosting effects also came into play as a result of the quantitative success of the labor market reforms. Because the more qualified workers primarily profited from this development, some form of skill bias was at work. Extending employment prospects, especially for the qualified workforce, changes the relative scarceness of workers. Competition among firms for highly qualified specialists could have forced employers to improve not only the remuneration package but also other dimensions of job quality to fulfill their recruitment targets. Overall, the sign of the overall effect of labor market reforms on working conditions is a priori not clear.

\subsection{International comparisons of job quality}

Several empirical studies address the evolution of the quality of working life at the international level. Typically, the studies identify a declining overall trend in the quality of working life (see Green/McIntosh 2001; or Green 2004; 2006). The indicators used by Greenan et al. (2012) give a mixed picture. Accompanied by more physical strain, work has become more intense but less complex. Germany and Italy are the only two countries with all indicators showing a decline in the (perceived) quality of working. Unfortunately, the data used ended in 2005, so the effects of the German reforms cannot be studied.

Of some importance for studying factors influencing job quality at the macro level and creating a basis for intertemporal and international comparison is the synthetic job quality index (JQI) of the European Trade Union Institute (cf. Leschke et al. 2008; 2012). Similar to the criteria as described in the previous section, "[the] job quality index is compiled on the basis of six sub-indices: wages, non-standard forms of employment (inverted), working time and work-life balance, working conditions and job security, access to training and career development, and collective interest representation' (ibid.: 5).

In condensed form, the results for Germany in this study are presented in Figure 4. The figure shows the change in the JQI and its components for Germany, the EU 15 and the EU 27 between 2005 and 2010, such that the reform effect is likely to be reflected. Somewhat astonishingly, there are marked changes only in two dimensions, whereas the other four dimensions feature insignificant changes. Moreover, one of the significant factors is negative, and the other one is positive. Hence both are more or less compensating each other, so the overall effect is of second order. The negative influence on the synthetic job quality index is related to the wage component. According to Leschke et al. (2012), the 


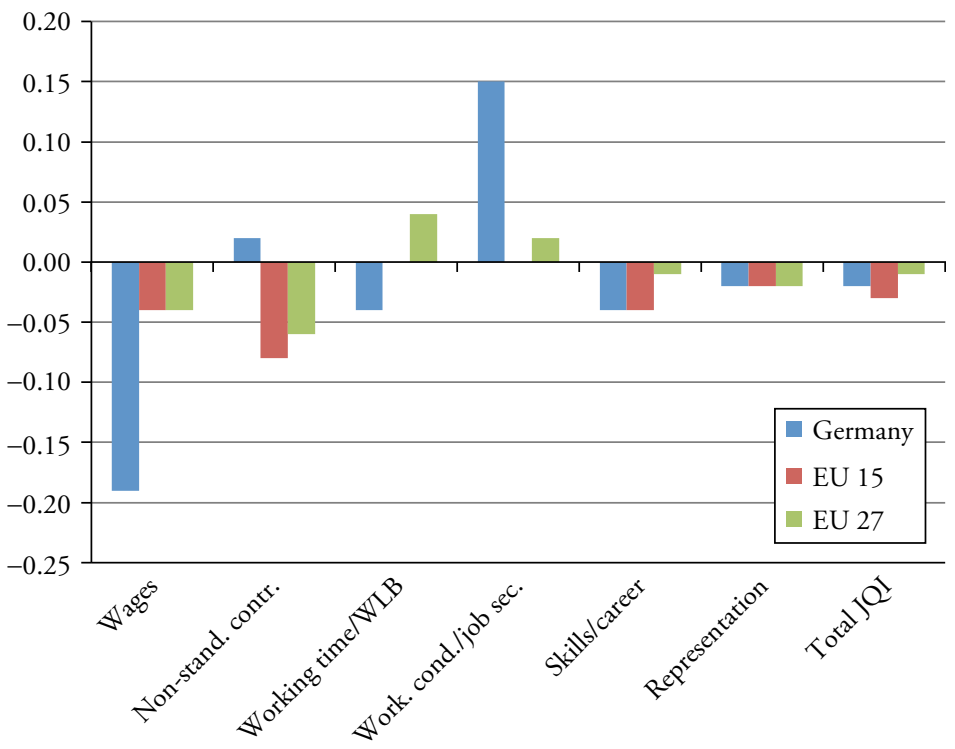

Source: Own representation with data from Leschke et al. (2012).

Figure 4 Changes in the Job Quality Index (JQI) and its components, 2005 to 2010

size of this factor is topped by only one of the $27 \mathrm{EU}$ countries, namely Romania. The positive component is related to working conditions and job protection. In this respect, Germany is among the five top-performing countries. At first glance, this is a puzzling outcome because the labor market reforms tightened the job acceptance rules for the unemployed. Hence, one would have expected a decrease in the perceived quality of working conditions. Moreover, job protection regulations were not substantially changed through the reforms - although, if anything, they were weakened. However, there is an important factor that might explain the result. This is the specific response of the German labor market to the World Recession. Despite the extreme shock to GDP, and in sharp contrast to firms in other countries, German firms restrained themselves with dismissals. Instead, one could have observed a massive labor hoarding phenomenon (see Möller 2010). This behavior of firms was strongly supported by subsidizing a reduction in working hours through the Federal Employment Services (Kurzarbeitergeld). As a result, mass lay-offs could be avoided. It is not unlikely that this behavior of firms - being strongly supported by the work councils and unions - was perceived as an increase in job stability.

\subsection{The shady side of the labor market: segmentation, inequality, instability}

The synthetic job quality index is based on the perceptions of workers. One can go beyond this approach and look for objective indicators that are likely to influence the quality of jobs not only for the majority but also for certain subgroups of workers.

One should stress that, even before the labor market reforms, several factors that influence the quality of working life indicators were changing. First, there is a declining trend in the share of standard employment for all groups of workers, as shown in Table 1. For young and low-skilled workers, the share of normal working contracts has declined to just 
Table 1 Share of standard employment contracts by age and skill level in three different years

\begin{tabular}{lccc}
\hline & 1991 & 1999 & 2007 \\
\hline Age & & & \\
$15-24$ & $56.2 \%$ & $35.9 \%$ & $28.1 \%$ \\
$24-49$ & $75.0 \%$ & $70.4 \%$ & $63.9 \%$ \\
$50-64$ & $73.9 \%$ & $69.4 \%$ & $65.3 \%$ \\
Skill level & & & \\
Low & $54.9 \%$ & $46.9 \%$ & $34.0 \%$ \\
Intermediate & $77.0 \%$ & $71.0 \%$ & $64.8 \%$ \\
High & $75.7 \%$ & $71.9 \%$ & $67.5 \%$ \\
\hline
\end{tabular}

Source: IAB.

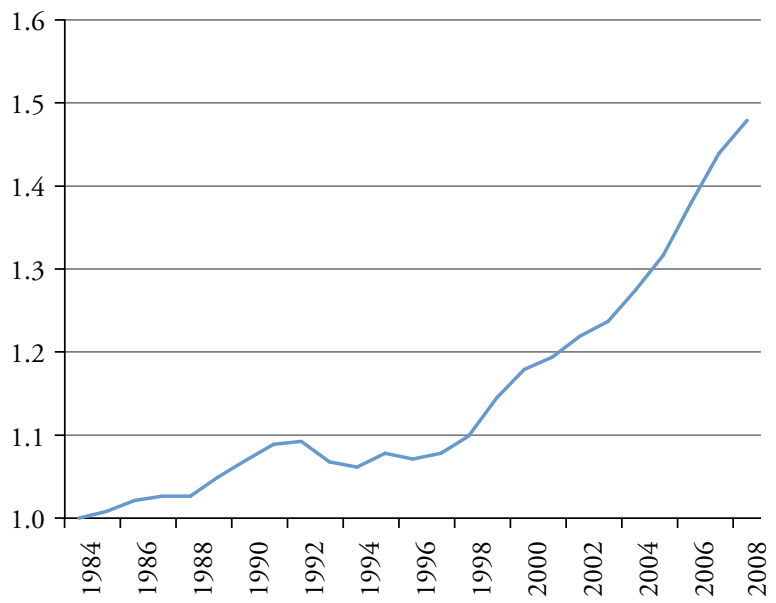

Note: Log. distance between the median and the second decile; full-time male workers in West Germany only. Source: Own calculations with SIAB.

Figure 5 Inequality Index $(1984=1), 1984-2008$

28 and 34 percent. In contrast, at the beginning of the 1990s, more than half of these workers had normal working contracts (that is, full-time permanent jobs eligible for social contributions outside the temporary work sector). Although non-standard employment contracts are not necessarily precarious, the probability that they have unfavorable characteristics such as low pay, short duration, and insufficient career prospects is considerably higher than for normal employment (see Dietz et al. 2013). Hence the marked growth of the share of atypical employment contracts might be a relevant explanatory factor for the decrease in the perceived quality of working life indicator. The development also points in the direction of an aggravated labor segmentation between 'good jobs' and 'bad jobs' in the economy. This brings us to an examination of wage inequality.

A reasonable indicator for overall wage inequality in the low tail of the wage distribution is the log difference between the median and the second decile. Figure 5 gives the result for the rather homogeneous group of male full-time workers in West Germany for the time period 1984 to 2008. Several aspects are worth mentioning. First, the wage inequality in 
the low tail of the distribution has increased significantly (see Möller 2008; Dustmann et al. 2009; Card et al. 2013; and others). Second, this marked increase had already begun in the second half of the 1990s. Third, the curve became steeper after 2005.

Taken together, evidence on wage inequality below the median shows a development that began long before the labor market reforms. The institutional changes that came along with the reforms did not initiate the trend towards more inequality. If anything, they led to its acceleration.

A recent international comparison indicates extraordinary growth of the low-pay sector in Germany (Rhein 2013). Almost a quarter of all employees received less than the lowpay threshold of $€ 9.54$ in 2010. According to Rhein (2013), Germany has moved from a country with intermediate earnings inequality to the top group in Europe. If all employees are considered, the size of the low-pay sector exceeds even the UK's. ${ }^{4}$

As a criterion for adequate remuneration, one can ask whether all major groups in the labor market participate in the overall increase in productivity. Figure 6 shows the average real gross earnings per calendar day for different skill groups. The sample is restricted to fully employed male workers at age 40 in West Germany. It is evident that earnings increase

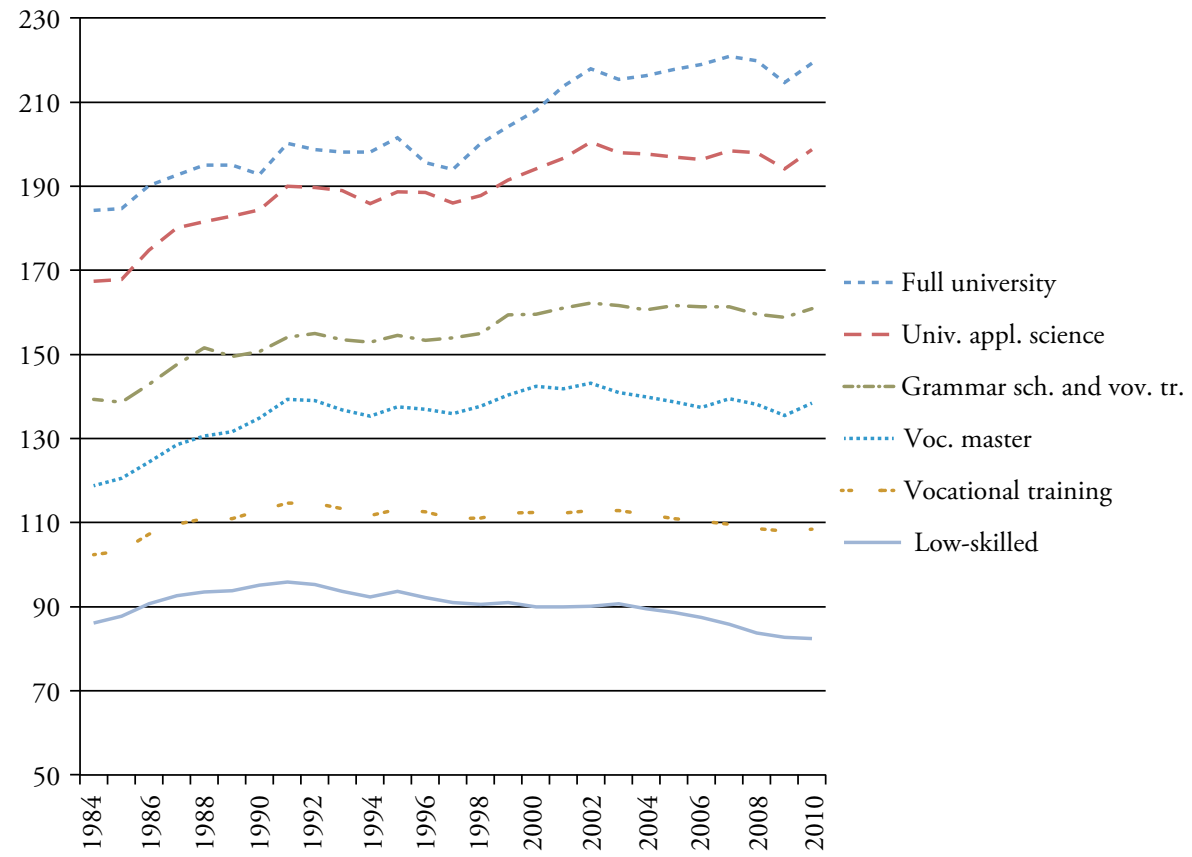

Source: Own calculations with SIAB.

Figure 6 Index of real gross earnings 1984-2010 of workers at age 40 by skill level (full-time male workers in West Germany only)

4. Besides wage inequality, it is also the decrease of wage income relative to profits that has to be mentioned in this context. From a macroeconomic perspective, the weak growth of aggregate household income might be seen as an important factor in explaining the weak domestic demand and current account surplus (see Behringer/van Treeck 2013). 
markedly with the qualification level. Whereas, at the end of the observation period, graduates from a university have daily gross earnings of $€ 220$, the low-skilled only have slightly above $€ 80$ (in 2005 euros). Furthermore, the spread between the high-skilled and the lowskilled rises over time. High-qualified workers were able to increase their earnings, while low-skilled workers suffered from remarkable losses. In 2010, an average 40-year-old lowskilled worker had a lower real wage than he had 25 years ago. After reunification, the real earnings of this group at first slightly decreased, then the development became rather flat, and from the middle of the first decade of the new century onwards, they were falling more strongly. For the large group of workers with basic schooling and completed vocational training as well as those with a vocational master's degree, the development was rather flat from the early 1990s onwards. The recent episode of falling real wages starts with the implementation of labor market reforms.

Figure 6 identifies the lower-skill groups as the disadvantaged. In real terms, their income has shrunk - especially since 2005 . Hence, these groups did not benefit from the favorable economic development in the long run. If adequate earnings are an element of good working conditions, one can state that this condition was violated for several groups with weak bargaining power.

For younger workers, the discrepancies are even more pronounced. Figure 7 gives the corresponding results for workers at age 30 . It can be observed that the earnings for younger workers are more volatile than those for older workers. The loss in real wages

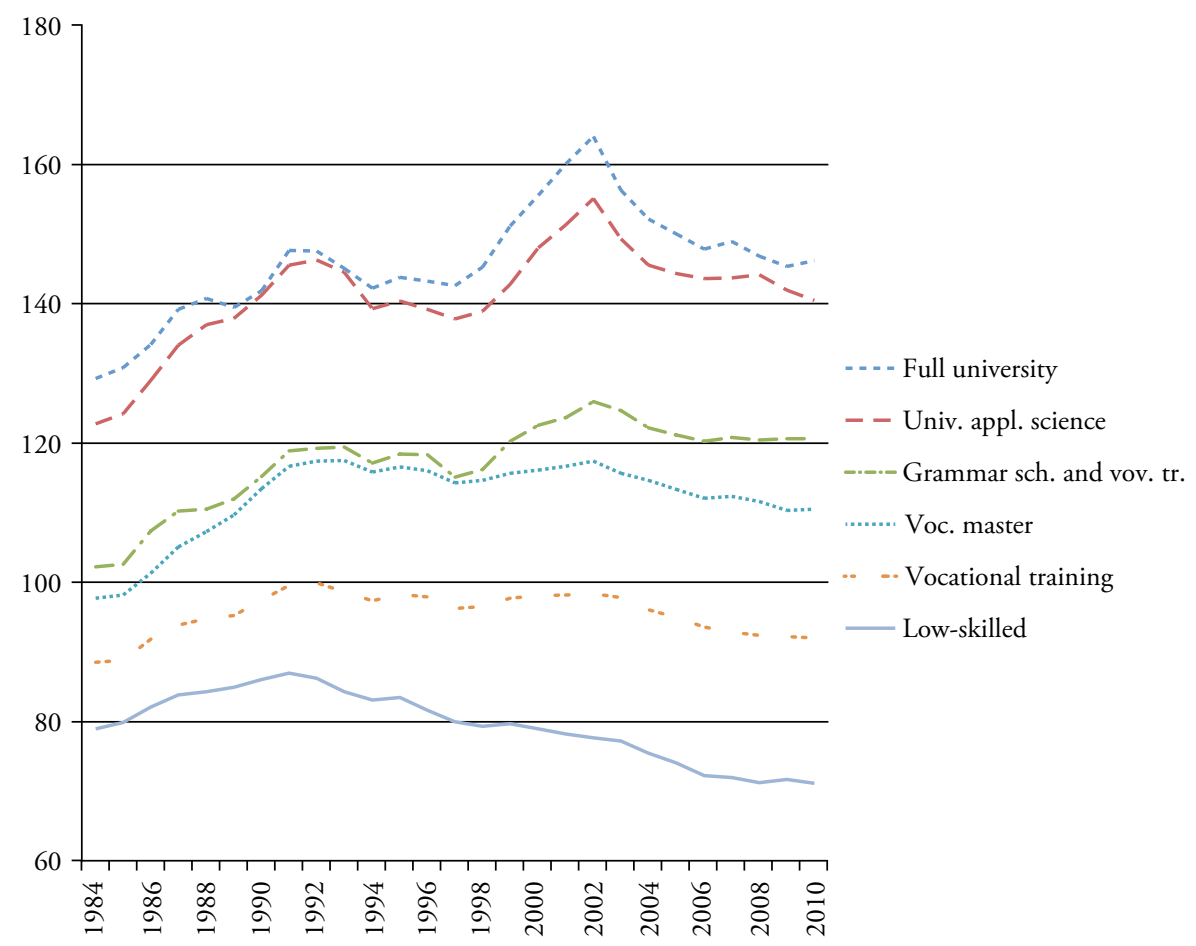

Source: Own calculations with SIAB.

Figure 7 Index of real gross earnings 1984-2010 of workers at age 30 by skill level (full-time male workers in West Germany only) 


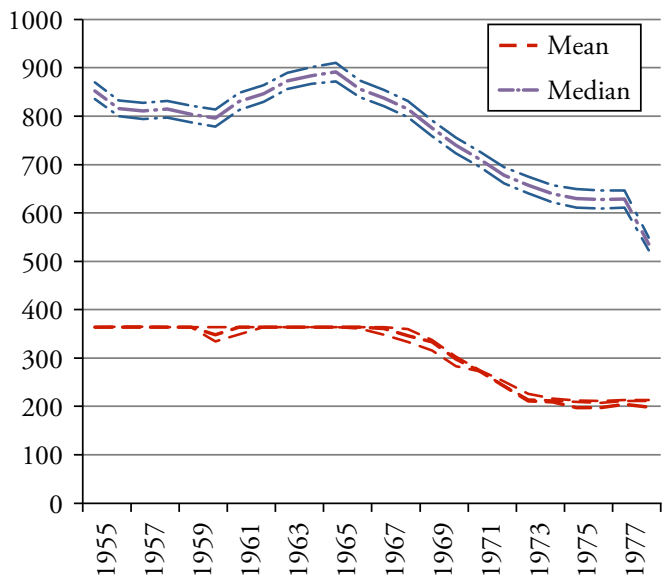

Figure 8 Length of employment spells below the age of 30 for different birth cohorts of workers (mean, median, and 95 percent confidence bounds)

for the low-skilled is now more significant. The earnings of the top two skill groups peaked at the turn of the century - that is, the time of the new-economy boom. Since then, this group has also experienced real wage losses.

Figure 8 shows Kaplan-Meier estimates for the average length of employment spells for workers below the age of 30 for different birth cohorts. Interestingly, the median spell length is rather stable until the birth cohort of 1965 . Since then, this indicator of employment stability has declined substantially. While median spell length was between 800 and 900 days, it declined to slightly above 600 days for the birth cohorts of 1975 and later. This is roughly a decline by one third. Insofar as the effect is not due to an increase in voluntary quits, the fall in median spell length indicates a loss in an important component of the quality of working life. Note that birth cohorts of the mid 1960s reached the age of 30 in the mid 1990s. Again, the trend towards a likely deterioration of job quality for certain groups of workers began well before the start of the labor market reforms. The mean length of employment spells is below the median, indicating a great deal of probability mass for very short spells.

A further point is the sizable increase in the share of workers getting wage subsidies to meet a subsistence level for them or their partner and children. Figure 9 shows the increase in subsidized employment (Aufstocker) by type of employment and wages after the labor market reforms. According to the figure, subsidized employment markedly increased after the reforms. A major share of this group receives monthly earnings below $€ 800$. $^{5}$

\subsection{Is there a quantitative/qualitative trade-off?}

I have presented strong evidence that labor market reforms had strong favorable effects on the quantitative indicators. Employment increased by a considerable amount, whereas short- and long-term unemployment fell sharply. Germany's labor market performance

5. It has to be mentioned that the low earnings in this group are partly due to short working time. However, hourly wages are, on average, very low. The results from the survey PASS, however, indicate that median hourly wage of the Aufstocker group is very low (€6.20 in 2011). 


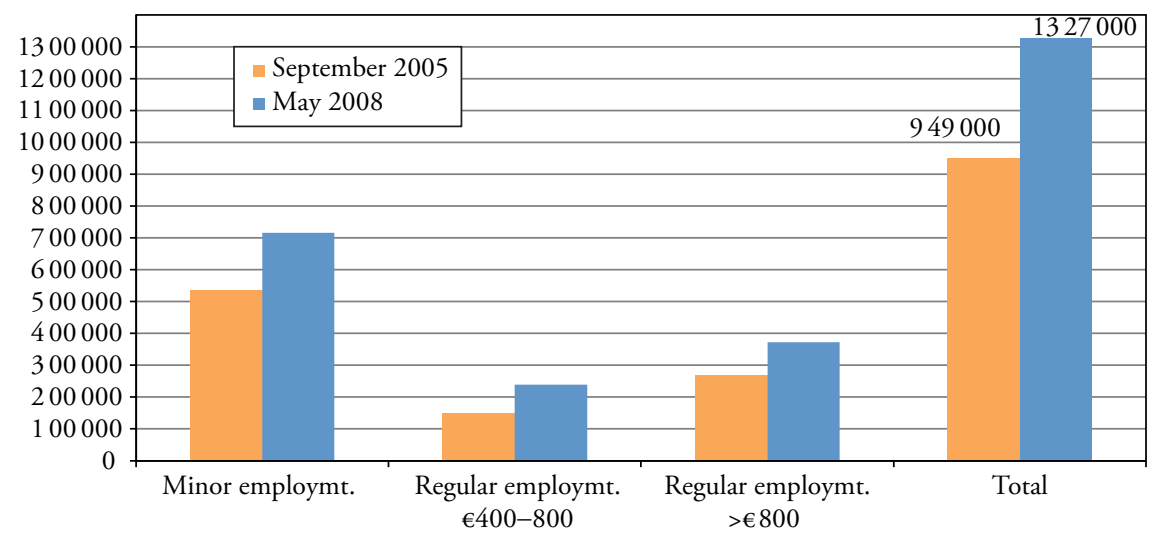

Figure 9 Workers with subsidized earnings (Aufstocker) in 2005 and 2008 by type of employment

with respect to youth unemployment is also remarkable good. On the negative side of the reforms, I mentioned the substantial increase of the low-pay sector, the sharp increase in inequality of earnings, and the higher number of working people receiving wage subsidies to obtain a minimum of earnings for them and their family. For young workers, there is also some indication that the mean and median spell lengths of employment have fallen markedly for those who were born after 1965. Overall, the empirical evidence presented here supports the view that one can expect a decreasing level of satisfaction with the quality of working life, at least for some groups. These developments, however, do not show up in the aggregate.

In assessing the quantitative/qualitative trade-off, one should refer to the two opposing views of the labor market. In a simplified version, one could say that the marked increase in the size of the low-pay sector was necessary to get less-productive workers into jobs. From an economic policy point of view, the increase in inequality was an instrument, not collateral damage. Put differently, the growth of the low-pay sector was the 'nature of the game' in this view. Any attempt to correct the development would jeopardize the employment successes. Of course, partisans of this viewpoint argue from a predominantly neoclassical position - that is, they view the labor market as an ordinary market with strong competitive forces, high market transparency, and low transaction costs. According to this position, egalitarianism would be costly in terms of jobs. For example, the current attempts to introduce a binding minimum wage would lead to an increase in unemployment, especially for the low-skilled, low-productivity workers. A similar argument applies to all measures aimed at stabilizing employment, such as longer contracts and a stronger regulation of temporary work agencies. From this viewpoint, there would be a strong case for a qualitative/quantitative trade-off.

The contrary view is taken by those who see the labor market as characterized by a lack of transparency and market power. In such a situation, regulations such as minimum wages could lead to an improvement in working life conditions at the low end of the wage distribution without jeopardizing the employment performance in the respective segment of the labor market. According to this position, the substantial increase of the low-pay sector was not necessary to improve the employment situation of the disadvantaged. Put differently, the increase in inequality was an unintended byproduct of the reforms, and measures to reduce inequality and instability would be welfare-increasing. 
How can these two positions be reconciled? First, one should stress that the deterioration of several factors responsible for perceived job quality or working life satisfaction had already begun a decade before the labor market reforms were implemented. For the increase in inequality, the poor development of wages for the low and intermediate skill groups, and the instability of employment for the young, the starting point was in the mid 1990s. The overall employment situation, however, improved only after the reforms were accomplished.

There are two alternative ways to interpret the evidence. The first is that for the success of the labor market wage restraint, higher inequality and instability were necessary, but not sufficient. They fostered the expansion of labor demand. But only after the institutional changes of the Agenda 2010 policy also mobilized the corresponding supply of workers, the positive development of employment and the reduction of unemployment were initiated. The second interpretation is that the instruments of the Hartz reforms by themselves were sufficient to improve the employment situation substantially. Then, at least, the decrease in work satisfaction through higher inequality and instability in the decade before were an unnecessary sacrifice.

Taking up an argument that I have previously used (in Möller 2014), one can examine the change in inequality for the sub-group of workers who were employed throughout the observation period. If inequality for this group has also increased, then there is some evidence for excess inequality. In this case, the increase in inequality cannot be motivated through the need to get low-productivity workers into work.

For the following analysis, I used SIAB data. The analysis was restricted to West German full-time workers. Female workers have a high incidence of working part-time. To reduce the possibility that the results would be biased because of persons being erroneously coded as part-timers, I excluded female workers.

I then divided the observation period from 1995 to 2010 into three sub-periods and restricted the sample to those workers who were employed at the beginning and end of the respective 5-year sub-periods. Assume that the wage is attached to the marginal productivity of the individual worker and the shape of the distribution of this individual characteristic is relatively fixed. Then, one would expect only a minor change of inequality measures within the group of continuously employed workers. Assume, further, that more wage inequality at the low end of the distribution was necessary to offer the low-productivity workers better employment opportunities. This would mean that a substantial increase of wage inequality should be observed, if one compares a wage inequality measure conditional to continuous employment with an inequality measure at the beginning of a new sub-period. The results of the calculations based on full-time workers in West Germany are shown in Figure 10. It is evident that the increase in inequality between the end of one sub-period and the beginning of the next is relatively small, whereas the major effect is within the sub-period for the continuously employed workers. The observed marked increase in inequality in the low tail of the wage distribution thus cannot be explained by the necessity to reduce wages to open employment chances for low-productivity workers. A point of view consistent with the empirical evidence is that there was - at least to some extent - an upsurge of wage inequality that cannot be justified by the need to create adequately remunerated workplaces for the disadvantaged. Hence, there should be some scope for reduction in wage dispersion without necessarily reducing the employment opportunities for low-productivity workers. This view is supported by the imperfect labor market approach that was developed by Alan Manning (2003) and others (for example, Boeri/van Ours 2013). As the quantitative/qualitative tradeoff is at least not as sharp as it might be observed from a purely neoclassical view of a fully competitive labor market, labor market policy has some room for maneuver to establish welfare-increasing measures through sensible regulations. 


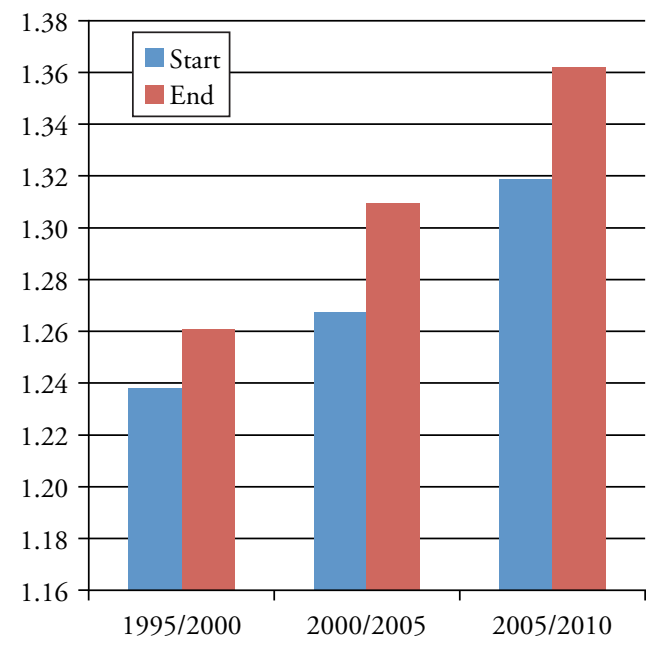

Source: Own calculations with SIAB.

Figure 10 Log decile ratio of the median and the second decile (D2) at the beginning and end of a 5-year period for continuously employed workers only

\section{CONCLUSIONS}

The paper argues that the German labor market reforms implemented in 2003-2005 were successful, according to the main quantitative indicator of labor market conditions. Longterm unemployment decreased substantially in the years after the reform, and the trend of continuously increasing systemic unemployment was reversed. At the same time, the extreme shock to the GDP by the world recession in 2008/2009 left only minor traces in the German labor market. Employment climbed to an all-time high and several regions, especially in Southern Germany, are close to full employment. Last but not least, youth unemployment in the country is one of the lowest in Europe.

In contrast to this, qualitative indicators of labor market developments give a mixed picture. First, there seems to be a negative long-run trend. Second, since 2005 there are negative and positive components that tend to counteract each other. I argued that the German 'job miracle' plays a major role on the positive side. The development of the level and structure of earnings, however, had an unambiguously negative influence on perceived job quality. Even before the labor market reforms, wage restraint beginning in the mid 1990s has led to the poor development of real wages for large groups of workers. In long-run comparisons, there are even large groups - especially among the low-skilled - that suffered from marked real wage losses. At the same time, job stability for specific groups - namely the young - diminished. Atypical types of employment grew strongly. As far as temporary contracts and involuntary part-time work are concerned, this typically implies a deterioration of satisfaction with working life, which seems also to correspond to indicators from internationally comparative surveys.

At first glance, one could suppose that a quantitative/qualitative trade-off for German labor market performance does exist. A closer look at the evidence, however, reveals that if the labor market is imperfect, improving job quality without jeopardizing the quantitative successes with respect to employment could be possible. I have presented an empirical analysis that challenges the orthodox view claiming that more inequality in the low tail of the distribution was necessary in order to create workplaces for the less productive part of the labor force. 


\section{REFERENCES}

Behringer, Jan, Van Treeck, Till (2013): Income distribution and the current account: a sectoral perspective, Institute for New Economic Thinking, INET Research Note \#035.

Blanchard, Olivier J., Summers, Lawrence H. (1987): Hysteresis in unemployment, in: European Economic Review, 31(1-2), 288-295.

Boeri, Tito, van Ours, J.C. (2013): Economics of Imperfect Labor Markets, 2nd edn, Princeton, NJ and Oxford: Princeton University Press.

Brücker, Herbert., Klinger, Sabine, Möller, Joachim, Walwei, Ulrich (2012): Handbuch Arbeitsmarkt 2013: Analysen, Daten, Fakten, Bielefeld: Bertelsmann W. Verlag (IAB-Bibliothek - Band 334).

Burda, Michael C., Hunt, Jennifer (2011): What explains the German labor market miracle in the Great Recession? in: Brookings Papers on Economic Activity, 42(1), 273-335.

Card, David, Heining, Jörg, Kline, Patrick (2013): Workplace heterogeneity and the rise of West German wage inequality, in: The Quarterly Journal of Economics, 128(3), 967-1015.

Dietz, Martin, Himsel, Carina, Walwei, Ulrich (2013): Wandel der Erwerbsformen - Welche Rolle spielen strukturelle Änderungen am Arbeitsmarkt? in: Arbeit: Zeitschrift für Arbeitsforschung, Arbeitsgestaltung und Arbeitspolitik, 22(2), 85-104.

Dustmann, Christian, Ludsteck, Johannes, Schönberg, Uta (2009): Revisiting the German wage structure, in: The Quarterly Journal of Economics, 124(2), 843-881.

European Foundation for the Improvement of Living and Working Conditions (2013): Industrial relations and working conditions developments in Europe 2012, URL: www.eurofound.europa.eu (accessed 28 January 2014).

Green, Francis (2004): Why has work effort become more intense? in: Industrial Relations, 43(4), 709-741.

Green, Francis (2006): Demanding Work: The Paradox of Job Quality in the Affluent Economy, Princeton, NJ: Princeton University Press.

Green, Francis, McIntosh, Steven (2001): The intensification of work in Europe, in: Labour Economics, 8, 291-308.

Greenan, Nathalie, Kalugina, Ekaterina, Walkowiak, Emmanuelle (2012): Has the quality of work improved in the EU-15 between 1995 and 2005? HAL Working Paper halshs-00682107, URL: http://ideas.repec.org/p/hal/wpaper/halshs-00682107.html (accessed 05 February 2014).

Hausner, Karl Heinz, Engelhard, Heidemarie, Weber, Enzo (2014): Kosten der Arbeitslosigkeit nochmals gesunken, IAB-Kurzbericht, 2-2014, Nürnberg.

Leschke, Janine, Watt, Andrew, Finn, Mairéad (2008): Putting a number on job quality? Constructing a European Job Quality Index, Working Paper 2008.03, Brussels: ETUI, URL: http://www.etui.org/ Publications2/Working-Papers/Puttinga-number-on-job-quality. Online verfügbar unter http:// www.etui.org/Publications2/Working-Papers/Puttinga-.

Leschke, Janine, Watt, Andrew, Finn, Mairéad (2012): Job quality in the crisis: an update of the Job Quality Index (JQI), ETUI Working Paper, 2012.07, URL: http://www.etui.org/Publications2/ Working-Papers/Job-quality-in-the-crisis-an-update-of-the-Job-Quality-Index-JQI (accessed 26 January 2014).

Manning, Alan (2003): Monopsony in Motion: Imperfect Competition in Labor Markets, Princeton, NJ: Princeton University Press.

Möller, Joachim (1990): Unemployment and deterioration of human capital: a labour market model with hysteresis implications, in: Empirical Economics, 15(2), 199-215.

Möller, Joachim (2008): Wage dispersion in Germany and the US: is there compression from below? in: International Economics and Economic Policy, 5(4), 345-361.

Möller, Joachim (2010): The German labor market response in the world recession: de-mystifying a miracle, in: Journal for Labour Market Research, 42(4), 325-336.

Möller, Joachim (2014): Prosperity, sustainable employment and social justice: challenges for the German labor market in the twenty-first century, in: International Journal for Educational and Vocational Guidance, 14(1), 35-46. DOI: 10.1007/s10775-013-9259-6. 3-881, May.

Rhein, Thomas (2013): Erwerbseinkommen: Deutsche Geringverdiener im europäischen Vergleich, IAB-Kurzbericht, 15/2013, Nürnberg. 